\title{
Long-Term Considerations on Constructing Academic Discourse
}

\author{
ZHANG Qing*
}

Now is not the first time that the problem of constructing Chinese academic discourse has been raised. This problem has repeatedly arisen ever since the advent of modernity in China. In essential form, it arose when, at the end of the Qing dynasty (1644-1911), China, as a result of outsider influence, faced challenges that had never before occurred in its three-thousand-year history. As the Zhuangzi states, "Scholars, with their controversies, will rend the empire asunder." It is in this context that modern Chinese scholarship has developed. Hence, it is necessary to consider this background in discussing the long-term development of modern Chinese thought and scholarship. On this basis we can assert that knowing the origin of the problem not only helps us to understand it, but also enables us to see that such a problem, even today, will provoke spirited discussion, and that we may have to reorient our work accordingly. Otherwise, we will end up repeatedly raising issues of the past and will find it difficult give the problem depth.

Subject knowledge, marked by its disciplinary focus, is for China a Western import. But "Western knowledge" and "Western disciplines" are historical categories that are not clearly demarcated. Moreover, from the beginning, the Western knowledge imported into China has always had a Chinese element added in.

Obviously, today's academic discourse directly shines light on the gradual growth of modern knowledge. Moreover, in gradually establishing modern disciplines characterized by specialized knowledge, China borrowed from the West. Two things are worth paying attention to here: (1) How was the Western concept of disciplines transmitted to China? (2) How did China

* Professor Zhang Qing is former Chair of the History Department at Fudan University and former President of the Society.

1 道術將為天下裂 (Zhuangzi 莊子, “Tianxia” 天下). 
introduce the Western concept of disciplines? We pursue this question of Western imports because there is no known Western background. Moreover, in the growth of China's modern knowledge, there are clear Japanese elements, in addition to Western elements.

Disciplines determine the form of historical space and time. Like Chinese disciplinary knowledge, Western disciplinary knowledge developed over the course of a long process. ${ }^{2}$ One thing is clear: the sciences did not all develop at the same pace. It is generally accepted that "astronomy came first. Then came physics in the sixteenth century. Chemistry was developed in the eighteenth century." And biology "developed only in the nineteenth century."3 Immanuel Wallerstein revealed that in the latter half of the nineteenth century, there were three tendencies that helped institutionalize science: (1) Universities established departments (or at least professorial positions) using the names of disciplines. (2) National, and later international, scientific organizations were established. (3) Libraries began to use disciplines to organize books by category. Many of the disciplines in the social sciences that we are accustomed to today - disciplines such as anthropology, economics, history, political science, and sociology - did not exist prior to the nineteenth century. It was only in the latter half of the nineteenth century that these disciplines became institutionalized. ${ }^{4}$ This shows that disciplinary knowledge in the West as well was a product of the transformation of society.

In the growth of modern China, disciplinary knowledge was intimately connected with each wave of transmission of Western learning to such an extent that we have to trace back to the transition from the Ming to Qing dynasty in order to discover its origins. From this alone, we can see that there has always been input from the receiving culture, that there never was pure transmission of knowledge. The transmitters, owing to their status, had wide discretion as to which areas of Western science to introduce to China, even to extent that they would suit Western knowledge to the Chinese framework for knowledge. And the receivers often took foreign knowledge and incorporated it into a framework for knowledge with which they were familiar. The Jesuits transmitted the understanding of knowledge of fifteenth- and sixteenthcentury Europe. So, for example, A General Outline of Western Learning 西 學凡, by the Jesuit Giulio Aleni (1582-1649), can be regarded as the essen-

2 David C. Lindberg, The Beginnings of Western Science: The European Scientific Tradition in Philosophical, Religious, and Institutional Context, 600 B.C. to A.D.1450 (Chicago: University of Chicago Press, 1992).

3 Abraham Wolf, A History of Science, Technology, and Philosophy in the Sixteenth and Seventeenth Centuries (London: Allen and Unwin, 1935).

4 Immanuel Wallerstein 华勒斯坦, Xueke, zhishi, quanli 学科·知识·权力 (Disciplines, Knowledge, and Power) (Beijing: Sanlian Shudian, 1999), pp.213-226. 
tials of courses of instruction of European universities. But Chinese accommodations are readily apparent. ${ }^{5}$ Hence, when we discuss Chinese absorption of Western knowledge, we should realize that "Western knowledge" and "Western disciplines" are both historical concepts, and that from the start when China absorbed Western knowledge, it added Chinese elements.

Not only that, this transmission of knowledge diluted the national distinctiveness of knowledge, to the point where late Qing talented individuals no longer felt constrained about acquiring Western disciplinary knowledge. A changed situation never before experienced in China's 3,000-year history thus arose in Chinese science. Zhang Taiyan 章太炎 (1868-1936), in "The Origin of Study" 原学, the first essay in the revised version of his Compelled Writings, wrote, "Looking at the sky and seeing how vast and hazy it is, those who would take a scientific position feel that they have nothing to rely on. Hence they rely on topographical similarities, regulations and custom, or the properties of materials, in order to express themselves, and on this basis call themselves a school of thought." Taiyan already felt that in an age when people could reach the four corners of the earth, the age of using topographical similarities and material properties to determine the direction of study had already passed. "Nowadays those who engage in the technical arts often consider society and its regulations and customs, in order to discern their direction."' After reading The Theory of Evolution 天演論, the translation by Yan Fu 嚴復 (1854-1921) of Thomas Huxley's Evolution and Ethics, Sun Baoxuan 孫寶瑄 (1874-1924) wrote, “The difference between Chinese scholarship and Western scholarship is that Chinese engage more in the study of the past, and Westerners engage more in the study of the future. What is the study of the past? Archaeology, for example. What is the study of the future? Administration and natural science are two examples. In explaining the Way, one can investigate the knowledge of the past, but I do not offer this as an

5 Xu Zongze 徐宗泽, Ming-Qing-jian Yesuhuishi yizhu tiyao 明清间耶稣会士译著提要 (A Synopsis of Jesuit Translations and Writings during the Ming and Qing Periods) (Shanghai: Zhonghua Shuju, 1949), p.289. Some commentators point out that it was quite reasonable for Xu Guangqi 徐光启 (1562-1633), Li Zhizao 李之藻 (15651630), and Yang Tingyun 杨廷等 (1562-1627), the three pillars of Chinese Catholicism, to adopt a receptive attitude toward the Jesuits' Christianized astronomy (an astronomy incorporated into their system of theology), in order to show that they accepted and wanted to study an advanced Western science (see Sun Shangyang 孙尚扬 and Zhong Mingdan 钟鸣旦 (Nicolas Standaert), 1840 nian qian de Zhongguo Jidujiao 1840年前的中国基督教 [Chinese Christianity before 1840] [Beijing: Xueyuan Chubanshe, 2004], p.206).

6 Zhang Taiyan 章太炎, “Yuan xue" 原學 (The Origin of Study), in Qiu shu xiang zhu 訄書詳注 (Compelled Writings, with Detailed Notes) (Shanghai: Shanghai Guji

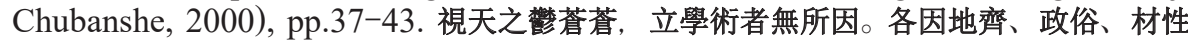
發舒, 而名一家。/ 今之為術者, 多觀省社會、因其政俗, 而明一指。 
example of knowledge of the past." "7 Here we can see late Qing scholars seeking, through their efforts in Chinese and Western scholarship, to create knowledge without national differences 國無異學.

In this learning without national differences, a universal notion of learning 學 replaced traditional notions of the Way 道 and substance 體, and was developed in discussions about universality and modernity. Yan Fu criticized the idea of “Chinese substance and Western function" 中體西用, writing, "Chinese learning has its own substance and function, and Western learning has its own substance and function. Separate them, and we can maintain both. Combine them, and they will both end up on the ash heap of history." $\mathrm{He}$ emphasized, "What China lacks is Western learning. Hence, it is clear that Western learning is the urgent task at hand." 8 Appropriate education proceeds according to the level of knowledge (primary school, middle school, high school). In On the Power of Knowledge to Change the World 論學術之勢力左 右世界, Liang Qichao 梁啟超 asserted, “In Heaven and Earth, there is only one power. What is it? It is called wisdom. It is called knowledge." ${ }^{9}$ Here he clearly attributes the differences between China and the West to learning and sees the competition between China and the West as lying in the field of learning. Furthermore, he thought that learning is not new or old, nor does it have a Chinese or Western perspective. He also saw Chinese and Western intellectual interaction as having reached a temporary resting place. Wang Guowei 王國維 (1877-1927) saw the controversies over useful versus useless knowledge, over Chinese versus Western learning, over traditional versus modern learning as all arising from lack of clarity regarding the significance of learning: "Those who speak of learning nowadays argue over new versus old learning, Chinese versus Western learning, useful versus useless learning. But I say to everyone, learning is not new or old, Chinese or Western, useful or useless. Those who use these descriptors do not learn and do not know

7 Sun Baoxuan 孫寶瑄, Wangshanlu riji 忘山盧日記 (A Diary of the Master of Wangshan Studio) (Shanghai: Shanghai Guji Chubanshe, 1983), vol.1, p.156. 今日中西學問之 分界, 中人多治已往之學, 西人多治未來之學。曷謂已往之學？ 考古是也。曷謂未來之 學？ 經世格物是也。惟閪道之學，能察往知來，不在此例。

8 Yan Fu 严复, “Yu Waijiaobao zhuren shu” 与〈外交报〉主人书 (Letter to the editor, Diplomatic News), in Yan Fu ji 严复集, edited by Wang Shi 王栻 (Beijing: Zhonghua Shuju, 1986), vol.3, pp.557-565. 中學有中學之體用, 西學有西學之體用, 分之則並立, 合之則兩亡。/ 中國所本無者, 西學也, 則西學為當務之急明矣。

9 Liang Qichao 梁启超, Lun xueshu zhi shili zuoyou shijie 论学术之势力左右世界 (On the Power of Knowledge to Change the World), in Yinbingshi heji 饮冰室合集 (Beijing: Zhonghua Shuju, 1989), photographic reporduction, vol.1, "Wenji zhi liu" 文集之六，pp.110-116. 天地間獨一無二之大勢力, 何在乎? 曰智慧而已矣, 學術而已 矣。 
what learning is." 10

As one can readily see from these quotes, Western learning 西學 became the new learning 新學, and the contest between China and the West became the contest between the old and the new. As one writer notes, "Western learning transcended the tension between Chinese versus Western identity and acquired a more universal name: the new learning."11 One can discern this transformation in the appearance of series of books with titles mentioning the new learning in place of books with titles mentioning Western learning. Among books promoting the new learning was one titled The Court Encyclopedia of the New Learning 皇朝新學類纂 (1901) and another titled The Great Encyclopedia of the New Learning 新學大叢書 (1903), modeled on Japanese works and thus showing that Japan at the turn of the twentieth century had gradually become the nation from which China absorbed the new learning. With the transition from "Western learning" to "the new learning," the universality of learning became more apparent. This universality not only was compatible with China's status as a backward nation, but also fixed the area of competition among nations in field of knowledge. Late Qing literati gradually came to accept that the competition between Chinese and Western culture would be determined on the battlefield of learning.

\section{In times of epistemological crises in modern China, transfers of power often found expression as transformations of the episteme. Nevertheless, we must also realize that the construction of the modern episteme is a global, universal affair.}

China accepted modern knowledge, with its disciplinary focus, for many reasons, but the most basic is that Chinese culture experienced an epistemological crisis in the modern period. An epistemological crisis as expounded by Alasdair MacIntyre is similar to Thomas Kuhn's notion of a paradigm crisis. People who live in one cultural tradition become immersed in its models and frameworks for perceiving and understanding the world. When the world changes so that they no longer understand it and their former concepts and frameworks no longer seem to help and indeed become obstacles to under-

10 Wang Guowei 王国维, “Guoxue congkan”xu 国学丛刊, 序 (“China Studies Series,” Preface), in Wang Guowei yishu 王国维遗书 (Shanghai: Shanghai Shudian Chubanshe, 1983), vol.3, p.202. 今之言學者, 有新舊之爭, 有中西之爭, 有有用之學與 無用之學之爭。余正告天下曰：學無新舊也, 無中西也, 無有用無用也。凡立此名者, 均 不學之徒, 即學焉而未嘗知學者也。

11 Luo Zhitian 罗志田, “Chuanjiaoshi yu jindai Zhong-Xi wenhua jingzheng” 传教士与 近代中西文化竞争 (Missionaries and the Modern Competition between Chinese and Western culture), Lishi yanjiu 历史研究 1996, no.6: 77-94. 
standing, this cultural tradition is in an epistemological crisis. ${ }^{12}$ In times of epistemological crises in modern China, transfers of power often found expression as transformations of the episteme. That is, the grounded intellectual resources and epistemological foundations for discussing ideas about the practical world and society came to be based on the development of disciplinary knowledge, and tradition ceased to serve as a resource for China's episteme. As one author made clear, one of the decisive changes that occurred during this period was that grounded discussion of ideas about society gradually forsook traditional intellectual resources and adopted modern ideas closely associated with the European Enlightenment. Such discussion made use of such ideas as equality, freedom, and the people to spin political narratives about society, and it sought grounded intellectual resources for the discussion in the new disciplines of sociology, anthropology, political science, and other social sciences. ${ }^{13}$

And yet this transformation of the episteme did not arise indigenously. In fact, from the nineteenth century on, the construction of the modern episteme has been a global affair. It began in the central societies of Europe, which then exercised their technological power over peripheral societies. Edward Shils regarded this as one of the surprising changes of modern societies, and he emphasized that this sort of change was the result of not only of the spreading influence of central societies on peripheral societies but also of peripheral societies' admiration of central societies. ${ }^{14}$ The changes that have occurred in Chinese society and culture in the last century are a direct result of the center-versus-periphery configuration that has emerged in the global human community from the nineteenth century on. As Chinese society gradually lost the beliefs, values, and symbolic order that it formerly defended, it looked to the central societies for a model to construct outward-looking beliefs, values, and symbolic order. Hence, the modern episteme in its

12 See Shi Yuankang 石元康, “Chuantong, lixing yu xaingduizhuyi” 傳統、理性與相對主 義 (Tradition, Rationality, and Relativism), in his Cong Zhongguo wenhua dao xiandaixing: Dianfan zhuanyi？ 從中國文化到現代性：典範轉移？ (From Chinese Culture to Modernity: A Paradigm Change?) (Taipei: Dongda Tushu, 1998), pp.328.

13 See Liu Xiaofeng 劉小楓, “Zhongguo wuzhengfuzhuyi yu xiandai wutuobang siwei” 中國無政府主義與現代鳥托邦思維 (Chinese Anarchism and Modern Utopian Thinking), Ershiyi shiji 二十一世紀 (Chinese University of Hong Kong), no.27 (February 1995): 43-52.

14 Edward Shils, Center and Periphery (Chicago: University of Chicago Press, 1975). I rely here on Ye Qizheng 葉啟政, "Bianchuixing yu xueshu fazhan: Zailun kexue Zhongguohua” 邊陣性與學術發展：再論科學中國化 (Peripherality and the Development of Science: A Reexamination of the Sinicization of Science), in Xiandaihua yu Zhongguohua lunji 現代化與中國化論集（Taipei: Guiguan Tushu, 1990), pp.221-262. 
Chinese variant is simply a reflection of Chinese society and culture being demoted from the center to the periphery. As a result, Chinese society and culture sought to identify and nearly entirely rely on the learning of central societies. (It is, of course, another matter whether China actually achieved this goal.)

From historical debates as well, one can see that around 1905, when China's civil service examination was abolished, some disciplines, under the guise of "new learning," promised to save Chinese society politically, economically, culturally, and educationally. And as the 1923 debate on science and philosophy of life 科學與人生觀 shows, the various debates raging in intellectual circles (including historical, social, and cultural circles) all concerned the development of such disciplines. Here one can sense the sensation that these debates caused. Starting with the debates on ancient history 古史辨 in the mid-1920s and 1930s, the idea of China's three golden ages, a former important ground for rational arguments concerning Chinese society, was dismantled, while construction of China's scientific discourse gradually bore fruit. As Qian Mu 錢穆 (1895-1990) said, "Chinese scientific circles of the 1930s had already developed a standard of objectivity." 15 To establish modern disciplines, an objective standard must not only overcome schools of thought and the master's discipline; it must also develop relevant academic institutions and learned societies. In short, it must have an institutional foundation.

Of course, our viewing the construction of modern knowledge as a universal, global task does not mean that all types of knowledge are universal, much less that China's development of science was simply a matter of transplanting and imitating, but perhaps from this development we can better understand the hardships that early Chinese scientists endured. One cause for concern is that the modern universal knowledge that has molded the Chinese humanities and social sciences this past hundred odd years has monopolized legitimate ideas about society deployed in arguments and has become a decisive factor in giving birth to and nurturing modern Chinese culture. Hence, if we accept the basic orientation of Chinese values and the urgent transformation of cognitive style in the modern period, then we have to value the work of scholars of that period working in the sciences, for it was their efforts that established in China the modern system of disciplinary knowledge.

15 Yu Yingshi 余英時, "You ji feng chui shui shang lin: Qian Mu yu xiandai Zhongguo xueshu” 猶記風吹水上鱗：錢穆與現代中國學術 (Remembering the Breeze on the Water: Qian Mu and the Development of Modern Chinese Scholarship), in his Qian Mu yu Zhongguo wenhua 錢穆與中國文化 (Qian $\mathrm{Mu}$ and Chinese Culture) (Shanghai: Shanghai Yuandong Chubanshe, 1994), p.15. 


\section{Contemporary Chinese disciplines became established as a result of modern global multidirectional transfers of culture. Hence, disciplines gradually lost their national differences, and the scientific enterprise became the common cultural property of all humanity.}

If in considering the establishment of academic discourse as a key factor of the modern age, we assert that the issue arose much earlier and thereby deny that raising this issue at present has much value, we are merely gesturing at an explanation. Since we cannot discern the nature of the issue at the source, repeating arguments of the past will not prove very productive in understanding the establishment of academic discourse. But by sorting out the process whereby modern disciplines became established in China, it is not difficult to understand that this process was the outcome of multidirectional transfers of culture, and that China was not unique in this regard. The process whereby practical Chinese society and intellectual resources for discussing legitimate ideas of society gradually departed from traditional forms of Chinese knowledge and adopted modern forms of knowledge not only formed an important link in the transformation of Chinese academic discourse, but also constituted a portion of the global development of academic discourse. In other words, disciplinary knowledge grouped under the headings of the natural sciences, social sciences, and humanities has gradually lost its national character and become the common property of all human civilization.

Compared to the natural sciences, the humanities and social sciences have more of a national character. If we look at China studies, this field in other countries is basically the history of a foreign nation. Whether such histories were written by Europeans or Japanese or Americans, they have all been developed on the basis of accumulated scholarly traditions. Specifically, they have their own particular traditions and senses of the issues, and they have developed their own systems of discourse and their own systems of nomenclature. For example, since social backgrounds and academic traditions change with different generations of scholars and with time, American Sinologists are discussing how they should follow through on their studies of China, how many connections and divergences they should seek in the issues that concern each generation of Sinologists. As one scholar pointedly asked, "Do only Western historians of China bring their cultural preconceptions into their research? And do not some explanatory paradigms entrenched in Chinese academic circles need to be reexamined?"16 In fact, Chinese histories

16 Zhu Zhenghui 朱政惠, "Meiguo xuezhe dui Zhongguoxue yanjiu de huigu yu fansi” 美国学者对中国学研究的回顾与反思 (American Scholars Retrospect and Reflect on Chinese Studies), Jianghai xuekan 江海学刊 2011, no.3: 149-159. 
of the West have shown the same sort of development.

Though there are many differences between Chinese and foreign scholarship, today's academic discourse no longer relies on appeals to authority in discussions of the past. By "authority" I mean, in addition to academic training, particulars like country of origin and sex (male versus female). Only by ridding ourselves of appeals to authority and engaging in scholarly criticism of particular research results can we return to scholarship itself and discuss its achievements and shortcomings. To be quite honest, Chinese discussions and Chinese experiences are in fact often bound up with appeals to authority, and Chinese scholars frequently engage in nitpicking about particulars, rather than discussing conceptual matters. Moreover, when discussions exude a certain smug self-righteousness, we had better keep our guard up. For this sort of attitude often leads to nitpicking about particulars, the idea being that only Chinese can truly understand Chinese history, and Chinese society, that research on China carried out by Chinese is superior to research carried out by scholars of other nations.

"If a nation lacks a navy, it is nothing to be ashamed of. If a nation lacks an army, it is nothing to be ashamed of. But if a nation lacks universities, public libraries, history museums, and museums of fine arts, then it has something to be truly ashamed of." 17 This quote is from the diary that Hu Shi kept when he was studying abroad in the United States. It reflects the hope of intellectuals of the time that China would develop academically. Academic development does indeed require system engineering, and in this regard, other nations have valuable experience in academic development that is worth studying. There are several reasons why. For one, there are considerable disparities in the academic resources of other nations. Nowadays many people criticize China studies programs in other countries, but have we considered the long tradition of China studies in the United States, Europe, and Japan, or the number of research organizations, or the number of China experts they have trained? And when we look at ourselves, what do we see? In research on history, many large nations, not to mention the nations of Latin America and Africa, lack the research organizations and experts of these nations. For another, there are also disparities in the conditions for academic research. To do research on Chinese history, to say nothing of the history of other nations, it is often necessary to visit libraries abroad to make use of books and materials housed there. A third reason is that our academic research lacks authoritative publications and critical forums to assure its

$17 \mathrm{Hu}$ Shi 胡適, Hu Shi liuxue riji 胡適留學日記 (Hu Shi’s Diary of Study Abroad), in vol.3 of $\mathrm{Hu}$ Shi zuopin ji 胡適作品集, no.36m》第36集, (Taibei: Yuanliu Chuban Gongsi, 1986), pp.4-5. 
credibility. I have said this for years, but not many journals and publishing companies in China can provide anonymous peer reviews. These are the problems that we face and need to solve in order to further our academic discourse. 